\title{
A Study on the Psychological Effect of Organizational Justice Perceptions on Job Satisfaction
}

\author{
Ms. Simran $\operatorname{Kaur}^{1 *}$
}

\section{ABSTRACT}

Employees' psychological capital has significant influences on his/her behavior in professional and personal life. Employees' perception about fairness in the organization tends to give rise to various favorable and unfavorable work outcomes. Job satisfaction is an example of such attitudinal variables which have is deeply affected by Organizational Justice Perceptions. Current literature of organizational Justice does not fully explain the mechanism governing the influence of organizational justice on job. This study tries to explain the relationship between organizational justice perceptions, job satisfaction, and Psychological Capital. The main objective of this study was to test the influence of organizational justice on job satisfaction, Psychological Capital. A survey-based methodology, with standardized scales was used. A sample of 218 employees from the Indian Public Sector Undertaking (PSU) was drawn The result obtained from Pearson correlation and stepwise multiple regressions suggest that Distributive Justice is found out to be the strongest predictor of organizational justice perceptions, job satisfaction, and Psychological Capital. It means that if people have favorable distributive justice perceptions, they are also likely to have positive organizational justice perceptions, job satisfaction, and Psychological Capital that has provided the favorable outcomes. Stepwise multiple regressions clearly indicate that various dimensions of Organizational Justice (Distributive, Procedural and Interactional Justice) can significantly predict the dimensions of Job Satisfaction (42.6\%), and Psychological Capital (19.7\%). The theoretical framework proposed in the paper on job satisfaction, and Psychological Capital; would help the researchers and management people to understand the impact of Perceptions about Organizational Justice in better efficiency of the organization.

Keywords: Psychological Capital, Organizational Justice, Job satisfaction, Fairness Perception, Indian PSU.

There is considerable research work to support the argument that fairness perceptions affect employees' attitudes and behaviors in the organizational context; however, researchers and practitioners do not seem to have an adequate understanding of the underlying mechanisms. The

\footnotetext{
${ }^{1}$ Assistant Professor, Delhi School of Professional Studies and Research, Affiliated to Guru Gobind Singh Indraprastha University, Dwarka, India

*Responding Author

(c) 2016 I S Kaur; licensee IJIP. This is an Open Access Research distributed under the terms of the Creative Commons Attribution License (http://creativecommons.org/licenses/by/2.0), which permits unrestricted use, distribution, and reproduction in any Medium, provided the original work is properly cited.
} 
purpose of this study is to further understand the influence of organizational justice on job satisfaction. Practitioners and researchers have acknowledged the significance of human capital in a dynamic business environment. It is evident that individuals differ in the degree of their commitment to the organization (Gouldner, 1960). The variations in the degree of commitment have raised questions for practicing managers; such variation is often influenced by employees' perception of justice (Korsgaard, Schweiger, \& Sapienza, 1995; Loi, Hang-Yue \& Foley, 2006; Lowe \& Vondanovich, 1995). Similarly, perceptions of justice are also found to influence job satisfaction, another significant variable showcased in the organizational literature (Ambrose, Hess, \& Ganesan, 2007; Elamin \& Alomaim, 2011).Moreover various forms of justice have been earlier linked to different facets of job satisfaction (Irving, et al., 2005).

Nowadays organizations need to create an environment for people where they feel that they have been treated fairly. Perception about Organizational Justice is a key concern for all employees at workplace. Concerns about fairness in organization exist in different aspects of employees' work life. Employees are concerned about the fairness in distribution of resources like rewards, pay, and so on. This is called Distributive Justice (Homans, 1901; Adams, 1963; Deutsch, 1975; Leventhal, 1976). Employees are also concerned about fairness in decision making process. This is termed as Procedural Justice (Thibaut and Walker, 1975; Leventhal, 1980). Finally employees also pay attention to fairness in interpersonal treatment. This is known as Interactional Justice (Bies and Moag, 1986; Greenberg, 1993). Collectively Distributive Justice, Procedural Justice and Interactional Justice are known as Organizational Justice. The term Organizational Justice was first coined by Greenberg (1987b). Organizational Justice refers to people's perception about organization's fairness and its reactions towards such perception. Unfair treatment not only decreases job performance but also reduces quality of work and degree of cooperation among workers (Fatimah, Amiraa and Halim, 2011).

Social Exchange theory acted as the basis for considering Psychological Capital as mediator between Organizational Justice, Job Satisfaction. Social Exchange theory explains how we consider a relationship with another person, depending on our perceptions of:

- The balance between what we put into the relationship and what we get out of it.

- The kind of relationship we deserve.

- The chances of having a better relationship with someone else.

In deciding what is fair, we develop a comparison level against which we compare the give/take ratio. This level will vary between relationships, with some being more giving and others where we get more from the relationship. They will also vary greatly in what is given and received. Thus, for example, exchanges at home may be very different, both in balance and content. Thus this theory involves involving two-steps:

- A person's behavior is contingent upon the reward from the environment; and

- The environmental reward is contingent upon the person's behavior (Emerson, 1976; Homans, 1958). 
On the basis of this theory, it can be concluded that positive organizational action (stimulus) which is perceived to be "fair" will lead to job satisfaction. An employees' perception of fairness will depend upon the comparison of received outputs with other comparable. This can be explained by Equity Theory, which states that employees try to maintain balance between the job inputs and outputs as compared to perceived job input and output ratio of others (Adams, 1966).

'Broaden and Build' theory of positive emotions can also be used to explain the mediation role of Psychological Capital in Organizational Justice, Job Satisfaction. This theory states that when positive emotional experiences occur, it leads to positive cognition, which allows an individual to build personal resources (Fredrickson, 2001; 2004). The relation between an employee and an organization is of social exchange. The employee enters this relation by taking organizational membership and the organization agrees to the same by giving such membership. At the most primary level, the employee would seek fair treatment in the organization; this assumption is in congruence with the view that justice is the most fundamental aspect of the workplace (Cosier \& Dalton, 1983). Further, just as injustice elicits negative emotions (Greenberg,1987), justice would elicit positive emotions. On the basis of the 'broaden and build' theory, it can be inferred that the perception of fairness that triggers positive emotions would result in broadening of the cognitive context. This in turn results in building up of the personal resources(Fredrickson, 2001; 2004). Following this, when an individual experiences building of personal resources because of perceived organizational justice, it is likely to cause an attitudinal or affective reaction to the job, and would also act as a cause for employee to identify with the organization perceived organizational justice, it is likely to cause an attitudinal or affective reaction to the job, and would also act as a cause for employee to identify with the organization. This attitudinal or affective reaction to the different aspects of the job is referred to as job satisfaction (Spector,1985); and the strength of an employee's identification and involvement with an organization is defined as (Curry, Wakefield, Price, \&Mueller, 1986; Porter, Steers, Mowday, \& Boulian, 1974).

Thus, the perception of organizational justice that contributes to making up of an individual's Psychological Capital would essentially translate into job satisfaction. Consistent with this reasoning, this paper develops and tests the mediation of Psychological Capital for the influence of organizational justice on job satisfaction.

Job satisfaction is a positive emotional (Smith, Kendall, \& Hulin, 1969) and attitudinal alignment towards a job (Spector, 1985); it is a main consequence of work experiences (Igbaria, Parasuraman, \& Badawy, 1994). This paper uses the five-factor conceptualization of job satisfaction, namely, satisfaction with work itself, pay, promotion, supervision, and coworkers (Stanton, et al., 2001). 


\section{OBJECTIVES OF THE STUDY}

The following objectives were framed for the study:

1. To determine the relationship between Organizational Justice and employees' job satisfaction

2. To determine the relationship between Organizational Justice and Psychological Capital.

3. To determine the relationship between Employees' Job satisfaction and Psychological Capital.

4. To determine the relationship between Psychological Capital and Employees' Job satisfaction

5. To determine if Employees' Psychological Capital can positively influences job satisfaction

6. To determine if Employees' Organizational Justice Perceptions can predict job satisfaction and Psychological Capital.

\section{RESEARCH METHODOLOGY}

\section{Research Structure}

The research structure is drawn according to the research purposes. The research structure is presented in Figure1. The structure means that the perspectives of research subjects for employee promotion and OCB

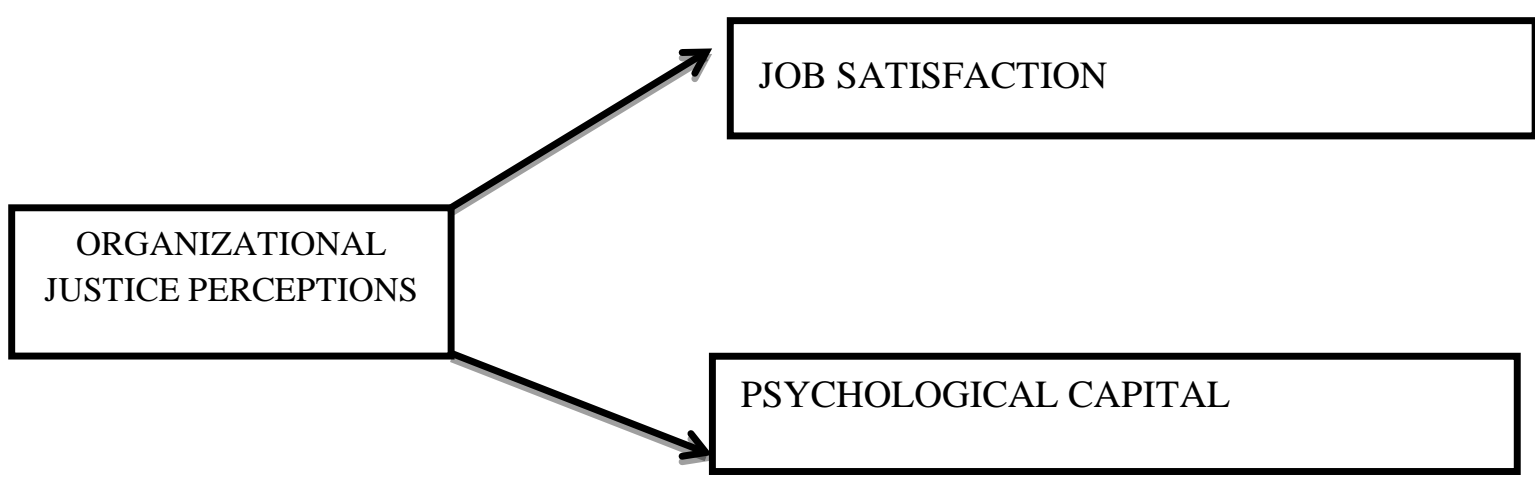

Figure 1: Research Structure

\section{Hypotheses}

Hypothesis 1: There is significant relationship between Organizational Justice and Job satisfaction.

Hypothesis 1a: There is significant relationship between Distributive Justice and Job satisfaction.

Hypothesis 1b: There is significant relationship between Procedural Justice and Job satisfaction. Hypothesis 1c: There is significant relationship between Interactional Justice and Job satisfaction. 
Hypothesis 2: There is significant relationship between Organizational Justice and Psychological Capital.

Hypothesis 2a: There is significant relationship between Distributive Justice and Psychological Capital.

Hypothesis 2b: There is significant relationship between Procedural Justice and Psychological Capital.

Hypothesis 2b: There is significant relationship between Interactional Justice and Psychological Capital.

Hypothesis 3: Organizational Justice can significantly predict the value of Job satisfaction. Hypothesis 3a: Distributive Justice can significantly predict the value of Job satisfaction. Hypothesis 3b: Procedural Justice can significantly predict the value of Job satisfaction. Hypothesis 3c: Interactional Justice can significantly predict the value of Job satisfaction.

Hypothesis 4: Organizational Justice can significantly predict the value of Psychological Capital.

Hypothesis 4a: Distributive Justice can significantly predict the value of Psychological Capital. Hypothesis 4b: Procedural Justice can significantly predict the value of Psychological Capital. Hypothesis 4c: Interactional Justice can significantly predict the value of Psychological Capital.

\section{Tools}

Scale 1: Organizational Justice Scale (Moorman, 1991)

This scale analyzed Organizational Justice in three dimensions - Distributive Justice, Procedural Justice and Interactional Justice. The scale had 20 items, 5 of these 20 items were developed for Distributive Justice, 6 for Procedural Justice and 9 for Interactional Justice. This is a 7 point scale and scores on the scale varies from 1= strongly disagree to $7=$ strongly agree.

Scale 2: Psychological Capital (Luthan, Youssef \& Avolio, 2007b)

This scale analyzed four dimensions of Psychological Capital: Hope, Optimism, self-efficacy and resilience. The scale had 24 items i.e., 6 items of each dimension. This is a 7 point scale and scores on the scale varies from $1=$ strongly disagree to $7=$ strongly agree.

Scale 3: Abridged version of Job Descriptive Index (Smith, et al., 1969; Stanton, et al., 2001) The Job Descriptive Index is perhaps the premier instrument for assessing job satisfaction. It is a multi-faceted assessment of job satisfaction that has been extensively used in research and applied settings for over 40 years. The short form or abridged JDI (a JDI) is used in this research work. In the JDI, each facet (or subscale) is composed of 5 items (25 items total). The facets are: work on present job; present pay; opportunities for promotion; supervision; and, coworkers. This is a 7 point scale and scores on the scale varies from $1=$ strongly disagree to $7=$ strongly agree. 


\section{Research Design}

The present study was Descriptive in nature.

\section{Sample}

The present study was conducted on 218 employees of Indian PSU. Respondent's brief profile is mentioned below:

\begin{tabular}{|c|c|c|c|c|}
\hline S.No. & \multicolumn{2}{|c|}{ Background of Respondents } & Number & Percentage \\
\hline \multirow[t]{2}{*}{01} & \multirow{2}{*}{ Gender } & Male & 184 & 84.4 \\
\hline & & Female & 34 & 15.6 \\
\hline \multirow[t]{4}{*}{02} & \multirow[t]{4}{*}{ Age Group } & $20-25$ years & 12 & 5.5 \\
\hline & & $26-30$ years & 30 & 13.8 \\
\hline & & 31 - 35 years & 15 & 6.9 \\
\hline & & Above 35 years & 161 & 73.9 \\
\hline \multirow[t]{4}{*}{03} & \multirow[t]{4}{*}{ Tenure of working } & Less than 1 year & 8 & 3.7 \\
\hline & & $1-5$ years & 45 & 20.6 \\
\hline & & $6-10$ years & 14 & 6.4 \\
\hline & & More than 10 years & 151 & 69.3 \\
\hline
\end{tabular}

Table 1: Respondents Profile

\section{FINDINGS AND DISCUSSION}

In statistics, Cronbach's (alpha) is a coefficient of internal consistency. It is commonly used as an estimate of the reliability of a psychometric test for a sample of examinees. Theoretically, alpha varies from zero to 1, since it is the ratio of two variances. Empirically, however, can take on any value less than or equal to 1 , including negative values, although only positive values make sense. Higher values of are more desirable.

\begin{tabular}{|l|l|l|}
\hline S.No. & Scales & $\begin{array}{l}\text { Cronbach's Alpha } \\
\text { Reliability } \\
\text { Coefficient }\end{array}$ \\
\hline 01 & Organizational Justice Scale (Moorman, 1991) & .878 \\
\hline 02 & $\begin{array}{l}\text { Abridged version of Job Descriptive Index (Smith, et al., 1969; } \\
\text { Stanton, et al., 2001) }\end{array}$ & .837 \\
\hline 03 & Psychological Capital (Luthan, Youssef \& Avolio, 2007b) & .836 \\
\hline
\end{tabular}

\section{Table 2: Reliability Alpha score}

The internal consistency of items was assessed by computing the total reliability of all the scale. The total reliability scale for the study is mentioned in Table 2, indicating an overall reliability factor as good for all the scales. This reliability value for study is substantial considering the fact that the highest reliability that can be obtained 1.0 . 


\section{DATA ANALYSIS METHODS}

\section{Correlation Analysis}

Pearson correlation coefficient was computed to find out the relationship between the variables:

\begin{tabular}{|c|c|c|c|c|c|c|c|c|c|c|c|}
\hline & & DJ & $\overline{P J}$ & IJ & SEC & HOP & RES & OPT & JS & $\mathrm{OJ}$ & PC \\
\hline \multirow[t]{2}{*}{ DJ } & $\begin{array}{l}\text { Pearson } \\
\text { Correlation }\end{array}$ & 1 & $.396^{* *}$ & $.414^{* *}$ & $.190^{* *}$ & $.139^{*}$ & $.139^{*}$ & $.190^{* *}$ & $.629^{* *}$ & $.694^{* *}$ & $.188^{* *}$ \\
\hline & Sig. (2-tailed) & & .000 & .000 & .005 & .041 & .041 & .005 & .000 & .000 & .005 \\
\hline \multirow[t]{2}{*}{ PJ } & $\begin{array}{l}\text { Pearson } \\
\text { Correlation }\end{array}$ & $.396^{* *}$ & 1 & $.674^{* *}$ & $.163^{*}$ & .076 & .076 & $.163^{*}$ & $.498^{* *}$ & $.884^{* *}$ & .129 \\
\hline & Sig. (2-tailed) & .000 & & .000 & .016 & .264 & .264 & .016 & .000 & .000 & .057 \\
\hline \multirow[t]{2}{*}{$\mathbf{I} \mathbf{J}$} & $\begin{array}{l}\text { Pearson } \\
\text { Correlation }\end{array}$ & $.414^{* *}$ & $.674^{* *}$ & 1 & $.197^{* *}$ & .123 & .123 & $.197^{* *}$ & $.505^{* *}$ & $.858^{* *}$ & $.180^{* *}$ \\
\hline & Sig. (2-tailed) & .000 & .000 & & .003 & .069 & .069 & .003 & 0 & .000 & .008 \\
\hline \multirow[t]{2}{*}{ SEC } & $\begin{array}{l}\text { Pearson } \\
\text { Correlation }\end{array}$ & $.190^{* *}$ & $.163^{*}$ & $.197^{* *}$ & 1 & $.374^{* *}$ & $.374^{* *}$ & $1.000^{* *}$ & $.308^{* *}$ & $.221^{* *}$ & $.724^{* *}$ \\
\hline & Sig. (2-tailed) & .005 & .016 & .003 & & .000 & .000 & .000 & .000 & .001 & .000 \\
\hline \multirow[t]{2}{*}{ HOP } & $\begin{array}{l}\text { Pearson } \\
\text { Correlation }\end{array}$ & $.139^{*}$ & .076 & .123 & $.374^{* *}$ & 1 & $1.000^{* *}$ & $.374^{* *}$ & $.205^{* *}$ & .132 & $.910^{* *}$ \\
\hline & Sig. (2-tailed) & .041 & .264 & .069 & .000 & & .000 & .000 & .002 & .052 & .000 \\
\hline \multirow[t]{2}{*}{ RES } & $\begin{array}{l}\text { Pearson } \\
\text { Correlation }\end{array}$ & $.139^{*}$ & .076 & .123 & $.374^{* *}$ & $1.000^{* *}$ & 1 & $.374^{* *}$ & $.205^{* *}$ & .132 & $.910^{* *}$ \\
\hline & Sig. (2-tailed) & .041 & .264 & .069 & .000 & .000 & & .000 & .002 & .052 & .000 \\
\hline \multirow[t]{2}{*}{ OPT } & $\begin{array}{l}\text { Pearson } \\
\text { Correlation }\end{array}$ & $.190^{* *}$ & $.163^{*}$ & $.197^{* *}$ & $1.000^{* *}$ & $.374^{* *}$ & $.374^{* *}$ & 1 & $.308^{* *}$ & $.221^{* *}$ & $.724^{* *}$ \\
\hline & Sig. (2-tailed) & .005 & .016 & .003 & .000 & .000 & .000 & & .000 & .001 & .000 \\
\hline \multirow[t]{2}{*}{ JS } & $\begin{array}{l}\text { Pearson } \\
\text { Correlation }\end{array}$ & $.629^{* *}$ & $.498^{* *}$ & $.505^{* *}$ & $.308^{* *}$ & $.205^{* *}$ & $.205^{* *}$ & $.308^{* *}$ & 1 & $.652^{* *}$ & $.290^{* *}$ \\
\hline & Sig. (2-tailed) & .000 & .000 & .000 & .000 & .002 & .002 & .000 & & .000 & .000 \\
\hline \multirow[t]{2}{*}{ AC } & $\begin{array}{l}\text { Pearson } \\
\text { Correlation }\end{array}$ & $.197^{* *}$ & $.348^{* *}$ & $.315^{* *}$ & $.567^{* *}$ & $.405^{* *}$ & $.405^{* *}$ & $.567^{* *}$ & $.437^{* *}$ & $.358^{* *}$ & $.554^{* *}$ \\
\hline & Sig. (2-tailed) & .004 & .000 & .000 & .000 & .000 & .000 & .000 & .000 & .000 & .000 \\
\hline \multirow[t]{2}{*}{$\mathrm{CC}$} & $\begin{array}{l}\text { Pearson } \\
\text { Correlation }\end{array}$ & $.250^{* *}$ & .113 & $.213^{* *}$ & $.783^{* *}$ & $.425^{* *}$ & $.425^{* *}$ & $.783^{* *}$ & $.295^{* *}$ & $.223^{* *}$ & $.666^{* *}$ \\
\hline & Sig. (2-tailed) & .000 & .095 & .002 & .000 & .000 & .000 & .000 & .000 & .001 & .000 \\
\hline \multirow[b]{2}{*}{ NC } & $\begin{array}{l}\text { Pearson } \\
\text { Correlation }\end{array}$ & $.241^{* *}$ & .113 & .119 & $.612^{* *}$ & $.286^{* *}$ & $.286^{* *}$ & $.612^{* *}$ & $.282^{* *}$ & $.183^{* *}$ & $.486^{* *}$ \\
\hline & Sig. (2-tailed) & .000 & .096 & .079 & .000 & .000 & .000 & .000 & .000 & .007 & .000 \\
\hline
\end{tabular}


A Study on the Psychological Effect of Organizational Justice Perceptions on Job Satisfaction

\begin{tabular}{|l|l|l|l|l|l|l|l|l|l|l|l|}
\hline \multicolumn{2}{|l}{} & DJ & PJ & IJ & SEC & HOP & RES & OPT & JS & OJ & PC \\
\hline \multirow{2}{*}{ OJ } & $\begin{array}{l}\text { Pearson } \\
\text { Correlation }\end{array}$ & $.694^{* *}$ & $.884^{* *}$ & $.858^{* *}$ & $.221^{* *}$ & .132 & .132 & $.221^{* *}$ & $.652^{* *}$ & 1 & $.197^{* *}$ \\
\cline { 2 - 11 } & Sig. (2-tailed) & .000 & .000 & .000 & .001 & .052 & .052 & .001 & .000 & & .004 \\
\hline \multirow{2}{*}{ PC } & $\begin{array}{l}\text { Pearson } \\
\text { Correlation }\end{array}$ & $.188^{* *}$ & .129 & $.180^{* *}$ & $.724^{* *}$ & $.910^{* *}$ & $.910^{* *}$ & $.724^{* *}$ & $.290^{* *}$ & $.197^{* *}$ & 1 \\
\cline { 2 - 11 } & Sig. (2-tailed) & .005 & .057 & .008 & .000 & .000 & .000 & .000 & .000 & .004 & \\
\hline \multirow{2}{*}{ OC } & $\begin{array}{l}\text { Pearson } \\
\text { Correlation }\end{array}$ & $.290^{* *}$ & $.241^{* *}$ & $.276^{* *}$ & $.835^{* *}$ & $.477^{* *}$ & $.477^{* *}$ & $.835^{* *}$ & $.427^{* *}$ & $.324^{* *}$ & $.727^{* *}$ \\
\cline { 2 - 11 } & Sig. (2-tailed) & .000 & .000 & .000 & .000 & .000 & .000 & .000 & .000 & .000 & .000 \\
\hline
\end{tabular}

It can be observed that there is significant relationship between Organizational Justice perceptions and Job Satisfaction as $r=0.652$ and hence $\mathrm{H} 1$ has been accepted at 0.01 level of significance. Distributive Justice is significantly correlated with Job Satisfaction ( $\mathrm{r}=0.624)$, thus H1a is accepted. Moreover Job Satisfaction is also correlated with Procedural Justice ( $r=0.498)$, and Interactional Justice ( $r=0.505)$. Hence H1b and H1c are also accepted.

It was also witnessed that there is very less level of significant relationship between Organizational Justice perceptions and Psychological Capital as $\mathrm{r}=0.197$ and hence H2 has been accepted at 0.01 level of significance. Distributive Justice is again significantly correlated with Psychological Capital ( $\mathrm{r}=0.188$ ), thus H2a is accepted. Psychological Capital is also correlated with Procedural Justice ( $r=0.129)$, and Interactional Justice $(r=0.180)$. Hence H2b and H2c are also accepted.

\section{REGRESSION ANALYSIS}

Regression analysis is being done to find the relationship between certain dimensions and variables. Linear regression attempts to model the relationship between two variables by fitting a linear equation to observed data. One variable is considered to be an explanatory variable, and the other is considered to be a dependent variable. All the three factors i.e. Distributive justice (DJ), Procedural justice (PJ) and Interactional justice (IJ) are taken as the independent variables while all other variables: Job satisfaction, and Psychological Capital are taken as the dependent variable. Stepwise Regression analysis has been done on the variables.

\begin{tabular}{|c|c|c|c|c|c|c|c|}
\hline Variables & $\mathbf{R}$ & $\mathbf{R}^{2}$ & $\begin{array}{l}\text { Adj } \\
\mathbf{R}^{2}\end{array}$ & $\begin{array}{l}\text { S.E. of } \\
\text { Estimate }\end{array}$ & $\begin{array}{l}\text { F- } \\
\text { value }\end{array}$ & Sig & Beta \\
\hline $\begin{array}{l}\text { JOB SATISFCATION } \\
\text { Distributive justice } \\
\text { Distributive justice, Procedural Justice } \\
\text { Distributive justice, Procedural Justice, } \\
\text { Interactional Justice }\end{array}$ & $\begin{array}{l}.629 \\
.685 \\
.697\end{array}$ & $\begin{array}{l}.396 \\
.469 \\
.486\end{array}$ & $\begin{array}{l}.393 \\
.464 \\
.479\end{array}$ & $\begin{array}{l}6.99895 \\
6.57667 \\
6.48513\end{array}$ & $\begin{array}{l}141.328 \\
94.844 \\
67.398\end{array}$ & $\begin{array}{l}.000 \\
.000 \\
.000\end{array}$ & $\begin{array}{l}.629 \\
.512, .295 \\
.481, \quad .485 \text {, } \\
.181\end{array}$ \\
\hline $\begin{array}{l}\text { PSYCHOLOGICAL CAPITAL } \\
\text { Distributive justice }\end{array}$ & .188 & .035 & .031 & 5.42929 & 7.905 & .005 & .188 \\
\hline
\end{tabular}




\begin{tabular}{|l|c|c|c|c|c|c|l|}
\hline $\begin{array}{l}\text { JOB SATISFCATION } \\
\text { (Dependent Variable) }\end{array}$ & .652 & .426 & .423 & 6.82165 & 160.143 & .000 & .652 \\
$\begin{array}{l}\text { PSYCHOLOGICAL CAPITAL } \\
\text { (Dependent Variable) } \\
\begin{array}{l}\text { ORGANIZATIONAL JUSTICE } \\
\text { (Independent Variable) }\end{array}\end{array}$ & .197 & .039 & .034 & 5.41986 & 8.685 & .004 & .197 \\
\hline
\end{tabular}

\section{Table 4: Stepwise Multiple Regression Analysis}

Table 4 represents Stepwise Multiple Regression Analysis to predict values of Job satisfaction, and Psychological Capital using various dimension of Organizational Justice. Job satisfaction has been predicted by Distributive Justice where $\mathrm{R}=.629, \mathrm{R}^{2}=.396$ and $\mathrm{F}=141.328$, Beta=.629. $39.6 \%$ variance in Job satisfaction is being caused by Organizational Justice. Distributive justice. Procedural Justice collectively explains 46.9 \% variance in Job Satisfaction. Distributive justice, Procedural Justice and Interactional Justice collectively explains almost $70 \%$ of variance in Job satisfaction. As a whole, Distributive Justice is found out to be the strongest predictor of Job Satisfaction.

Distributive Justice with calculated as $\mathrm{R}=.188, \mathrm{R}^{2}=.035$ and $\mathrm{F}=7.905$, Beta=.188, explains $3.5 \%$ of variance in prediction of Psychological Capital

Organizational Justice explains $42.6 \%$ variance in Job Satisfaction, and $19.7 \%$ variance in Psychological Capital.

Following table represents the hypothesis and its results:

\begin{tabular}{|c|c|c|}
\hline HYPOTHESIS & SUB- HYPOTHESIS & RESULTS \\
\hline \multirow{3}{*}{$\begin{array}{l}\text { Hypothesis 1: There is } \\
\text { significant relationship } \\
\text { between Organizational } \\
\text { Justice and Job } \\
\text { satisfaction. }\end{array}$} & $\begin{array}{l}\text { Hypothesis 1a: There is significant relationship between } \\
\text { Distributive Justice and Job satisfaction }\end{array}$ & Accepted \\
\hline & $\begin{array}{l}\text { Hypothesis 1b: There is significant relationship between } \\
\text { Procedural Justice and Job satisfaction. }\end{array}$ & Accepted \\
\hline & $\begin{array}{l}\text { Hypothesis 1c: There is significant relationship between } \\
\text { Interactional Justice and Job satisfaction. }\end{array}$ & Accepted \\
\hline \multirow{3}{*}{$\begin{array}{l}\text { Hypothesis 2: There is } \\
\text { significant relationship } \\
\text { between Organizational } \\
\text { Justice and Psychological } \\
\text { Capital }\end{array}$} & $\begin{array}{l}\text { Hypothesis 2a: There is significant relationship between } \\
\text { Distributive Justice and Psychological Capital. }\end{array}$ & Accepted \\
\hline & $\begin{array}{l}\text { Hypothesis 2b: There is significant relationship between } \\
\text { Procedural Justice and Psychological Capital. }\end{array}$ & Accepted \\
\hline & $\begin{array}{l}\text { Hypothesis 2c: There is significant relationship between } \\
\text { Interactional Justice and Psychological Capital. }\end{array}$ & Accepted \\
\hline \multirow{3}{*}{$\begin{array}{l}\text { Hypothesis 3: } \\
\text { Organizational Justice } \\
\text { can significantly predict } \\
\text { the value of Job } \\
\text { satisfaction. }\end{array}$} & $\begin{array}{l}\text { Hypothesis 3a: Distributive Justice can significantly predict } \\
\text { the value of Job satisfaction. }\end{array}$ & Accepted \\
\hline & $\begin{array}{l}\text { Hypothesis 3b: Procedural Justice can significantly predict the } \\
\text { value of Job satisfaction. }\end{array}$ & Accepted \\
\hline & $\begin{array}{l}\text { Hypothesis 3c: Interactional Justice can significantly predict } \\
\text { the value of Job satisfaction. }\end{array}$ & Accepted \\
\hline
\end{tabular}




\begin{tabular}{|l|l|l|}
\hline Hypothesis 4: & $\begin{array}{l}\text { Hypothesis 4a: Distributive Justice can significantly predict } \\
\text { Organizational Justice } \\
\text { the value of Psychological Capital. }\end{array}$ & Accepted \\
\cline { 2 - 3 } $\begin{array}{l}\text { can significantly predict } \\
\text { the value of }\end{array}$ & $\begin{array}{l}\text { Hypothesis 4b: Procedural Justice can significantly predict the } \\
\text { value of Psychological Capital. }\end{array}$ & Rejected \\
\cline { 2 - 3 } Psychological Capital. & $\begin{array}{l}\text { Hypothesis 4c: Interactional Justice can significantly predict } \\
\text { the value of Psychological Capital. }\end{array}$ & Rejected \\
\hline
\end{tabular}

Table 5: Hypothesis Results

\section{CONCLUSION}

The need for the study was particularly because the existing literature on the relationship between fairness, satisfaction. The existing literature has not fully explained the possible causes for the influence of organizational justice on job satisfaction. The main focus of this study was to establish a relationship between perception about Organizational Justice and Job Satisfaction, Organizational Justice and Psychological Capital. On the basis of the result of this study, it can be concluded that there is a significant relationship between Organizational Justice and Psychological Wellbeing. The study revealed that Organizational Justice is correlated with Job Satisfaction ( $\mathrm{r}=0.652)$, and Psychological Capital $(\mathrm{r}=0.197)$. Thus organizations consider fairness in distribution, procedure and interaction in order to foster Job Satisfaction, and Psychological Capital. This study examined various direct relationships and it proved organizational justice as an antecedent of job satisfaction, and Psychological Capital.

\section{MANAGERIAL IMPLICATIONS}

Present study attempted to measure the impact of Organizational Justice Perception on job satisfaction, and Psychological Capital. The results suggested that there is positive relationship between Organizational Justice and job satisfaction, and Psychological Capital. Moreover all the variables under study i.e., job satisfaction, and Psychological Capital can be significantly predicted by various dimensions of Organizational Justice. Further, Organizational Justice has high correlation with Job satisfaction. Distributive Justice seems to have highest impact on all the variable of the study. Improvement in the perceptions towards Distributive Justice will in turn result into improvement in job satisfaction. This can be done by permitting employees to involve in the distribution of their own Resource (e.g.: wage). It can be an operational method to stimulate an employees' belief in the fairness of distribution of that resource. As pay arrangements redirect the distribution of consequences and distributive justice; organizations should ensure complete discussion of the employee compensation plan or at least, limit the level of confidentiality. The capability to offer "cafeteria-style” assistances can not only support the organization in dropping its whole costs, but the employee is also involved in the decisionmaking process and is able to better realize the costs to both him/herself and the organization. Organizations will certainly find it fairly challenging to include employee in every phase of its internal and external procedures. Therefore, they must include and influence effective communication and frequent feedback throughout all touch-points of the employment life cycle- 


\section{A Study on the Psychological Effect of Organizational Justice Perceptions on Job Satisfaction}

from start to finish. Both vital essentials significantly contribute to fairness in the workplace, further leading to improvement in employees’ job satisfaction level.

\section{LIMITATIONS}

This study is limited by the sample characteristics as it was conducted amongst employees drawn from single Indian PSU. The participants were predominantly male. It is not known whether the results would be applicable to other contextual settings or organizations. Generalizability of the present findings should therefore be examined in future research for other types of organizations, for mixed gender, and for more heterogeneous samples.

\section{REFERENCES}

Adams, J. S. (1965). Inequity in Social Exchange. In L. Berkowitz (Ed.), Advances in experimental social psychology, 2, 267-299.

Adams, J. Stacey (1963). Toward an understanding of inequity. Journal of Abnormal and Social Psychology,67, 422-436.

Barnard, C.I. (1938). The Functions of the Executive. Cambridge, MassHarvard University Press.

Bateman, T.S. \& Organ, D.W. (1983). Job satisfaction and the good soldier: the relationship between affect and citizenship. Academy of Management Journal, 26, 587-595.

Bies, R. J., \& Moag, J. (1986). Interactional justice: Communication criteria of fairness. In R. J. Lewicki, B. H. Sheppard, \& M. Bazerman (Eds.), Research on negotiation in organizations,1, 43-55. Greenwich, CT: JAI Press.

Cohen-Charash, Y., \& Spector, P. E. (2001). The role of justice in organizations: A metaanalysis. Organizational Behavior and Human Decision Processes, 86,278-321.

Cohen-Charash, Y., \& Spector, P. E. (2001). The role of justice in organizations: A metaanalysis. Organizational Behavior and Human Decision Processes, 86, 278-321.

Cropanzano, R., Rupp, D. E., Mohler, C. J., \& Schminke, M. (2001). Three roads to organizational justice. In J. Ferris (Ed.), Research in personnel and human resources management, 20, 1-113. Greenwich, CT: JAIPress.

Cropanzano, R.., Prehar, C. A., \& Chen, P. Y. (2002). Using social exchange theory to distinguish procedural from interactional justice. Group and Organizational Management, 27, 324-351.

Deci, E. L., \& Ryan, R. M. (1985). Intrinsic motivation and self-determination in human behavior. New York: Plenum

Deutsch M. 1975. Equity, equality and need: what determines which value will be used as the basis for distributivejustice? Journal of Social Issues ,31,137-149.

Diener, E., Tay, L., \& Oishi, S. (2013). Rising income and the subjective well-being of nations. Journal of Personality and Social Psychology, 104, 267-276.

Fatimah, O., Amiraa, A. M. \& Halim, F. W. (2011). The relationships between organizational justice, organizational citizenship behavior and job satisfaction, Pertanika J. Social Science \& Humanity, 19, $115-121$. 


\section{A Study on the Psychological Effect of Organizational Justice Perceptions on Job Satisfaction}

Folger, R. (1977). Distributive and procedural justice: Combined impact of "voice" and improvement on experienced inequity. Journal of Personality and Social Psychology, 35,108-119.

Gilliland, S. W., \& Hale, J. (2005). How do theories of organizational justice inform just employee selection practices? In J. Greenberg \& J. A. Colquitt (Eds.), Handbook of organizational justice: Fundamental questions about justice in the workplace, 411-438. Mahwah, NJ:Erlbaum.

Greenberg, J. (1987). Taxonomy of organizational justice theories. Academy of Management Review, 12, 9-22.

Huseman, R., Hatfield, J., \& Miles, E. (1987). A new perspective on equity theory: The equity sensitivity construct. The Academy of Management Review, 12, 222-234.

Katz, D. \& Kahn, R. (1966). Social Psychology of Organizations. New York, NY: Wiley.

Konovsky, M. A., \& Pugh, S. D. (1994). Citizenship behavior and social exchange. Academy of Management Journal, 37, 656-669.

Leventhal, G. S. (1976). The distribution of rewards and resources in groups and organizations. In L. Berkowitz \& W. Walster (Eds.), Advances in experimental social psychology, 9, 91131. New York: Academic Press.

Leventhal, G. S. (1980). What should be done with equity theory? New approaches to the study of fairness in social relationships. In K. Gergen, M. Greenberg, \& R. Willis (Eds.), Social exchange: Advances in theory and research, 27-55. New York: Plenum.

Moorman, R. H. (1991). Relationship between organizational justice and organizational citizenship behaviors: Do fairness perceptions influence employee citizenship? Journal of Applied Psychology,76, 845-855.

Moorman, R. H., \& Blakely, G. L. (1995). Individualism-Collectivism as an individual difference predictor of organizational citizenship behavior. Journal of Organizational Behavior, 16, 127-142.

Netemeyer, R. G., Bowles, J. S., MacKee, D. O., \& McMurrian, R. (1997). An investigation into the antecedents of organizational citizenship behaviors in a personal selling context. Journal of Marketing, 61, 85-98.

Niehoff, B. P., \& Moorman, R. H. (1993). Justice as a mediator of the relationship between methods of monitoring and organizational citizenship behavior. Academy of Management Journal, 36, 527-556.

Organ, D.W., 1988. Organizational Citizenship Behavior: The Good Soldier Syndrome. Lexington Books. Lexington, MA.

Ryf , C. D. (1989a). Happiness is everything, or is it? Explorations on the meaning of psychological well-being. Journal of Personality and Social Psychology, 57(6), 10691081.

Ryf , C. D. (1989b). In the eye of the beholder: Views of psychological well-being among middle-aged and older adults. Psychology and Aging, 4(2), 195-210. 
Skitka, L. J., Winquist, J., \& Hutchinson, S. (2003). Are outcome justice and outcome favorability distinguishable psychological constructs? A meta-analytic review. Social Justice Research, 16, 309-341.

Tang, T. L. P., \& Sarsfield-Baldwin, L. J. (1996). Distributive and procedural justice as related to satisfaction and commitment. S.A.M Advanced Management Journal, 2, 25-31.

Taylor, M. S., Tracy, K. B., Renard, M. K., Harrison, J. K., \& Carroll, S. J. (1995). Due process in performance appraisal: a quasi-experiment in procedural justice. Administrative Science Quarterly, 40, 495 - 523

Thibaut, J., \& Walker, L. (1975). Procedural justice: A psychological analysis. Hillsdale, NJ: Erlbaum.

Tyler, T. R., \& Blader, S. L. (2000). Cooperation in groups: Procedural justice, social identity, and behavioral engagement. Philadelphia, Psychology Press. 